\title{
Sacral Spinal Cord
}

National Cancer Institute

\section{Source}

National Cancer Institute. Sacral Spinal Cord. NCI Thesaurus. Code C12896.

The portion of the spinal cord located in the sacral region. 